\title{
College Students' Cognitive and Affective Attitude toward Higher Education and Their Academic
} Engagement

\author{
Damianus Abun ${ }^{1}$, Theogenia Magallanes ${ }^{2}$, Mary Joy Incarnacion ${ }^{3}$
}

${ }^{1}$ Ph.D: Divine Word College of Vigan, and St. Benedict College of Northern Luzon, Philippines

${ }^{2}$ Ed.D: St. Benedict College of Northern Luzon, Philippines

${ }^{3} \mathrm{Ph} . \mathrm{D}$ : Divine Word College of Vigan, Philippines

\begin{abstract}
The study was intended to determine the college students' cognitive and affective attitude toward higher education and how it affects their academic engagement. In order to proceed with the study, theories on human attitude and human behaviour and academic engagement were discussed. Related literatures were reviewed to strengthen the theory of the study and the validated questionnaires were used to gather the data. The study used descriptive correlational research design and supplied by inquiries. To interpret the data, the statistical tools were used such as Mean and Pearson r. Mean was used to measure the cognitive and affective attitude of students toward education and their academic engagement. Pearson $r$ was used to determine the relationship between cognitive and affective attitude of students toward higher education and academic engagement. The study found that students' cognitive and affective attitude toward higher education correlates significantly to the academic engagement.
\end{abstract}

Keywords-Cognitive attitude, affective attitude, academic engagement, behavioural and emotional engagement.

\section{RATIONALE}

In the Philippines context, education system has just changed particularly basic education curriculum. It used to be only ten years for basic education. The Philippine government considers the ten years system of education is disadvantageous against other countries and Asian Countries particularly. Philippines was the only among Asian countries that implemented the ten years of basic education (Uyquiengco, n.d)but since 2013, the basic education becomes twelve years with additional two years. The additional two years of basic education is called Senior High School. At this level, the students are choosing their own interest of specialization that will help them to acquire certain basic skills. It is expected that after completing the Senior High School, the students have acquired basic skills and are qualified for early employment. But beyond that, the purpose of the extension is to prepare Filipino students to be ready and better equipped to join overseas universities and therefore can compete globally.With this new extension, Filipino students have enough time to master skills and concepts so that they are prepared for tertiary education (ICEF Monitor, 2013).
Senior High School curriculum is nothing new for other countries in the world because they have twelve years basic education ever since. However, though Senior High school have prepared students the basic skills for work, but the Senior high School diploma has never been used as requirement for an employment in the current years. For example, Indonesia or Malaysia. They still look for college diploma as basic requirement for employment particularly higher jobs. Specializations that are offered at the Senior High School level are only to prepare them to go to University and deepen their knowledge and skills that they have acquired at the Senior High school level. Higher education is still necessary for everyone to get in order to get a better employment or better job. The same in the Philippines, though Senior High School have prepared students for basic skills and are qualified for employment but students and parents are still interested to pursue higher education.

Along such trend, the current study would like to know how the Filipino students perceive higher education. The success of students at higher education depends on how they perceived the higher education. The researcher believes that one's attitude affects his behavior or his engagement in 
his/her studies. Thus, by knowing his/her ideas and feelings or attitude about higher education, the school can anticipate on what to do with their curriculums in order to accommodate such expectations.

\section{Objective of the Study}

The purpose of the study is to help the school management to provide a curriculum that can answer the expectations of students. At the same time, it helps the teachers to prepare themselves to deliver knowledge and skills according to the expectations of students. The school and the teachers should be able to fulfill the expectations of students.

\section{THEORETICAL FRAMEWORK}

\section{Understanding Human Attitude}

Human attitude refers to the thoughts, beliefs, feelings and behavior of a person toward certain subject, person, object or institution or event (Cherry, 2019). It is a tendency to evaluate things according to his own perception, ideas or feelings. Thus, one can have favorable or unfavorable opinion or feeling toward certain subject, object, person, group, institution, events, etc. It becomes individual disposition to react in a favorable or unfavorable way toward certain subject, object, institution or event (Ajzen, 1993). The question is where does one get or learn those attitudes? Attitude is a result of upbringing or culture which later influence the behavior of the person toward certain subject or object, person, institution or event, etc. According to Ajzen (1993), attitude is a result of exposure or experience such as watching television or other kinds of exposure. Watching television orients someone to form an opinion toward certain thing. But Abun (2018) went deeper into the formation of attitude, that attitude is formed by the culture. He contends that attitude is formed by the culture where one is raised. His opinion is based on what Donald (2002), Hofstede as cited by Brown (1995). Donald argued that culture is playing important role in our brain functioning and even the brain structure. This view is in line with what Hofstede in Brown (1995) as he argued that culture is the collective programming of the human mind that can distinguish one human group from another. This opinion was also strengthened by the opinion of Amstrong (1996) that ethical perception of people is very much influenced by the culture. In this case ethical judgment of one person is depending on the culture where is brought up.

Ajzen (1993) contends that there can be a lot of definition about attitude depending on the orientation of certain psychologist but despite of those differences, they have common agreement. They agreed that though attitudes are latent or invisible but it can be evaluated (Bem, 1970, Edwards, 1957, Fishbein \& Ajzen, 1975). Attitude can be measured through the reaction or responses of the person toward the object of the attitude which may be favorable or unfavorable toward the object, persons, institution, events or situations. According to Allport, (1954), Hilgard, (1980), Rosenberg \& Hovland, (1960), Ajzen, (1993) that there are three categories of responses or reactions toward the object of the attitude and they are cognitive, affective and behavioural responses. Cognitive component of attitude refers to the thought, perception or ideas of the person toward the object of the attitude. Affective component is about emotional reaction or feeling of the person toward the object of the attitude such as like or dislike. While behavioral or conative component of attitudes is related to behavioral reaction toward the object of the attitude. After one knows the subject, object, institution, or event is emotional and behavioural reaction toward them and then what he/she is going to do or not to do.These may include plans, intentions and commitments to a planned behavior.

\section{The Influence of attitude toward Behavior}

We go back to the idea of attitude and how it affects the behavior. Attitude as we have pointed out earlier is feeling, an idea, perception or evaluation of a certain subject, object, person or institution, etc. It can also be defined as a psychological tendency which is expressed through evaluation of a particular object or subject with some degree or favor or disfavor (Eagly \& Chaiken,1998). It is a set of emotions, beliefs, and behaviors toward a particular object, person, thing, or event (Banaji \& Heiphetz, 2010). Such emotion or belief can be ranging from extremely negative to extremely positive toward the object of attitude. It is possible that one can have both idea or feeling toward a certain object in the sense that one can have negative and positive idea or feeling toward the same object or subject (Wood, 2000). It is an individual disposition of mind and a response or reaction toward the object of the attitude which influence individual action. This definition is in line with Jung's definition of attitude, that attitude is a "readiness of the psyche to act or react in a certain way (Main, 2014). However, such attitude is not coming out of the blue but it is formed from past and present experience (Allport, 1935). Since it is formed through learning or experience, thus attitude is not static but dynamic in the sense that attitude can change. Exposure to the object of attitude affects how a person forms his or her attitude toward such object. Repeated exposure of the 
individual to such object is a sufficient condition for the enhancement of his attitude toward it (Zajonc, 1998).

The idea on the influence of attitude toward behavior is an old idea since 1918, 1925 when Thomas \& Znaniecki, (1918) and Watson, (1925) contended that attitude is a key to understand human behavior. Their idea on the attitude and behavior influenced the researchers to conduct research on the effect of attitude toward behavior. Originally, their ideas were taken for granted for quite sometime by the early researchers until later time their ideas were challenged by the findings of new studies. The new investigators challenged the assumption through field studies on the relationship between attitude and behavior. Later studies found that there was no or little correlation between attitude and behavior. Let us take Corey (1937), Freeman and Ataoey (1960) as cited by Ajzen (1993) who conducted a study on students' attitude and cheating behavior. Their study found that there was no correlation between students' attitude and cheating behavior ((Ajzen, 1993, p.74). Even later study on the attitude and behavior supported the finding of Corey (1937), such as Dean (1958) who conducted a study on the attitude toward labor unions and participating in labor union meetings, and his study found no correlation. Similar study on measuring the effect of attitude toward behavior, Wicker and Pomazal, (1971) found that attitude toward a participating a subject in social psychology and actual participation in social psychology class was not correlated.

Their findings somehow discouraged later researchers to continue studying the effect of attitude toward behavior. Their findings challenged the importance of studying personal disposition toward behavior. As a result, most social psychologists accepted the negative verdict of the relationship between attitude and behavior. Instead of continuing the same study, they recommended to study of social context and norms as determinant factor in predicting human behavior. They contend that human behavior is influenced by social context and norms (De Fleur \& Westie, 1958, Deutscher, 1969).

However, later social psychologists such as Ajzen and Fishebin $(1977,2000$,) still defended the old theory that attitude is key predictor toward human behavior which was also supported by Allport (1968). Allport (1968) still considered attitude as key predictor toward behavior and in fact he emphasized that attitude is "the most distinctive and indispensable concept in contemporary American social Psychology" (p. 59). Ajzen (1993) explained that the inconsistencies in the earlier studies is not in the attitude and behavior themselves but it was a result of other factors such as response biases of the respondents, the multidimensionality of attitudes that were not taken into consideration of the study, and other moderating variables such as self-efficacy, self-awareness, self-monitoring, experience, knowledge or information, time pressure, etc. Rosenberg \& Hovland, (1960) criticized the earlier inconsistencies as a result of single construct, in the sense that those studies were measuring attitude as a single construct,not a multidimensional construct which include cognitive, affective and conative or behavioral construct. According to him measuring attitude alone without giving attention of the three dimensions do not do justice to the complexity of attitude construct (Allport, 1935).

\section{Attitude toward Higher Education}

It cannot be denied that attitude is still recognized as a key predictor toward behavior as pointed out by Znaniecki, (1918) and Watson, (1925). Their ideaswere supported by later social psychologists such as Ajzen and Fishebin (1977, 2000 ,). Both argue that attitude is key determining factor in predicting human behavior. This idea was getting stronger when Allport (1968) emphasized that attitude is "the most distinctive and indispensable concept in contemporary American social Psychology" (p. 59). Though their ideas were challenged by field researches which disproved the relationship between attitude and behavior, however there were also studies that support their ideas such as the study of Abun (2017) on the relationship between environmental attitude and environmental behavior. His study concluded that there is a relationship between environmental attitude and environmental behavior. He also conducted the study on entrepreneurial attitude and entrepreneurial behavior of students and the study found that there is a correlation between entrepreneurial attitude and entrepreneurial behavior of students (Abun, 2018).Fitzsimmons (2005) also proved the relationship between entrepreneurial attitude and entrepreneurial behavior.

Based on their theories, findings and arguments, we have no doubt to argue that knowing the attitude of students toward education is very important to understand their behavior when they are engaging in actual academic exercise. The concern here is how they look at higher education or how they regard higher education. It may be thatthey look at higher education as a way for them to land a job in the future and to become successfulas found by the study of Immerwahr, (2004), or as a way of improving economic and social well-being (Mandal, et.al, 2018) and a way of getting employment (Pillai \& Joseph, n.d). However, though some have positive attitude toward higher education, not few of 
them have also negative view about higher education because it is expensive and other factors such as unpreparedness (Immerwahr, 2004, Roy \& Kareem, 2016). Given this fear, however, many still believe that higher education help improve quality of life (Roy and Kreem, 2016). It has been the public perception of higher education, that the higher education is an instrument for social and economic development (Benjamin, 1993). Specifically, students and parents also have seen that there is no other alternative to improve one's life except through pursuing higher education. Studies had shown that when comparing the quality of life of high school graduate and college graduate, it revealed that college graduate had longer life span, better heath and dietary practices, better access to health care, greater economic security and stability, more prestigious employment, greater community service and leadership, has more self-confidence and less criminal activity and incarceration (Allen, 2007). Along this line, schools have been seen as a venue to develop certain personal and social qualities or aptitudes to be good citizen, to gain knowledge and skills (Pearson, et.al, 1997, Mandal, et.al, 2018).

\section{Academic Engagement}

In recent years, researchers have come out with different concepts of academic engagement as a result of their investigation on academic engagement (Fredricks, Blumenfeld, \& Parks, 2004). They came out with different definitions of academic engagement, for example Audas \& Willms (2002) define engagement as a form of students' participation in academic- and non-academic-related activities as well as their identification withthe school and everything in it such as values, rules or norms.Engagement in this sense is not limited to classroom activities but it includes other activities initiated by the school to enhance students' learning. The concept of academic engagement emphasizes the participation and identification. Academic participation involves activities inside and outside classroom such as class discussion, home assignment, not skipping classes, etc. While identification refers to the identification with the school, with the teachers, with the subject matter, with the related values or rules of the school. However, we are warned that academic engagement is not all about the amount or the quantity of participation but it is about the quality of engagement, the quality of students' participation with learning activities in the classroom ranging from energized, enthusiastic, focused, emotionally positive toward all academic activities. Thus, it might be good to see how Skinner, Kindermann, \& Furrer (2009) define academic engagement. For them, academic engagement is the quality of students' participation with the schooling endeavor and hence with activities, values, people, goals, and place that comprise it. This definition still defined the academic engagement behaviorally, not emotionally. Therefore, weare cautioned by social psychologists that engagement is not about behavioral engagement only but it is also emotional engagement. Along this line, Newmann, Wehlage, \& Lamborn (1992) give us a view of what psychological engagement means. For them engagement is students' psychological effort and investment toward learning, understanding, or mastering the skills, crafts, or knowledge that the schoolwork is intended to promote or psychological emotion needed to master and understand skills and knowledge explicitly taught at educational institution (Wehlage, Rutter, Smith, Lesko, \& Fernandez (1989).

Based on the definition above, we have the idea that academic engagement has three dimensions such as behavioral, cognitive and conative or emotional engagement. Though there are different opinions from different social psychologists, however they came to an agreement on the dimensions which commonly are utilized in defining academic engagement. In terms of behavioral dimension, Fredrick, et.at, (2004), Fin, et.al (1995) and skinner (1993) identify three ways in defining behavioral engagement such as first is positive conduct which include obeying the norms of the classroom or the school, and avoiding destructive behaviors. Second is participation in learning and academic related tasks and participation in class discussions. The third is involvement in related school activities such as school organizations, and sports (Fredrick, et.al, 2004). In relation to cognitive dimension, it involves students' investment in learning, disciplining one's self to understand the tasks, willingness to extend efforts to understand and master difficult tasks, using different strategies to understand the subject matter, finding ways to master the tasks including asking questions, studying, etc. Finally, emotional dimension or affective dimension refers to motivational engagement, psychological engagement and affective engagement which include students' positive and negative emotional reactions toward their teachers, classmates, academic work and the school as a whole (Fredrick, et.al, 2004).

From the concept of academic engagement, we come to a conclusion that academic engagement encompasses engaged behavior and engaged emotion. Engaged behaviors includes efforts and persistence, attention and concentration. Beside engaged behavior is engaged emotion which includes positive academic emotions such as enthusiasm, interest and 
enjoyment (Meyer \& Turner, 2002, Pekrun, Goetz, Titz \& Perry, 2002, Schutz \& DeCuir (2002, Weiner, 1985). Beside academic engagement, we have also academic disengagement which may consist of disaffected behavior and disaffected emotion. Disaffected behavior refers to behavioral disengagement which include passivity of students toward academic activities and other school related activities. For example, students who physically withdraw from activities and giving up (Murdock, 1999). Further, disaffected emotions are related to emotional disengagement which include emotional withdrawal in which students withdraw emotionally. Though students are physically present but emotionally they are not engaging the class. This can be seen in students who are frustrated, disruptive and just going through the motions (Finn, Pannozzo, \& Voelkl, 1995).

\section{RELATED STUDIES ON ATTITUDE TOWARD HIGHER EDUCATION}

The researcher tries to find related studies on the topic to enrich the discussion on the matter but there were very few researches that have been conducted similar to the topic. There were several studies similar to the current study but they were not exactly the same topic as the current topic we are developing particularly to measure the relationship between attitude of students toward higher education and academic engagement. Previous studies were only focusing on measuring the students' attitude toward education, for example, Malmstrom and Oqvist (2018) conducted a study on students' attitude toward higher education and intention and grade performance. The study was motivated by the curiosity of the researcher to find out what drives young people to engage in higher education. The study found that students' attitude toward higher education correlates to intention and academic performance but the study failed to identify the exact attitude that drives them to higher education.Similar study was done by Afzal and Rashid (2018) on the attitudes of students toward higher education and the difference between male and female attitude toward education. The study found that students have positive attitude toward higher education and there was no difference between male and female. Though Malmstrom and Oqvist (2018), Afzal and Rashied (2018) failed to identify exactly what drives students to pursue higher education, however, Pillai and Joseph (n.d) identified particular attitude as the reason behind why the students pursue higher education. The study pointed out that the students have very positive attitude toward higher education and have seen higher education as a training for an employment. Students believe that getting higher education assures them of getting good employment. The finding of Pillai and Joseph is strengthened by the study of Maheswari and Haridas (2013) on the attitude of students toward higher education. The study found that students have seen higher education as a guarantor for them to realize their career goals and dreams. The students see higher education as training ground to gain knowledge, skills and prepare them for employment and improve their life. The finding is supported by the study of Allen (2007). He tried to compare the life of High School graduate and College graduate. His study found that college graduate has better life compared to High School graduate. College graduate has longer life spans, better health practices and dietary, better access to health care, greater economic security and stability, better employment and greater job satisfaction, less dependency on government assistance, greater knowledge of government, greatercommunity service and leadership, more volunteer work, more self-confidence, and less criminal activity and incarceration.

Given the positive attitude toward higher education, the public and the students however, have seen higher education negatively. For example, Roy and Kareem (2016) conducted a study on the public attitude toward higher education. Though they recognized the importance of pursuing higher education as requirement for employment, nevertheless, the public have seen higher education negatively. The reason that they found primarily was that higher education becomes expensive and only few can afford it. Moreover, schools have neglected their role to provide skills necessary for employment. In this case, parents perceived that higher education should provide the necessary skills for employment and therefore higher education should be like technical education but such expectation is not met. This negative perception was further found in the study of Mawi and Maisnam (2014). They studied on the perception of students toward higher education. Though the students acknowledged the importance of higher education as a tool for getting employment, however, many students have negative attitude toward higher education because of the poor facilities and lack of trained teachers or instructors. This finding was also similar to the finding of Curran \& Rosen (2006). Curran and Rosen found the reason why students have negative attitudes toward higher education such as physical environment of the school, physical environment in which the course is conducted, the course topic, the course execution and instructors' personality.

\section{Conceptual Framework}




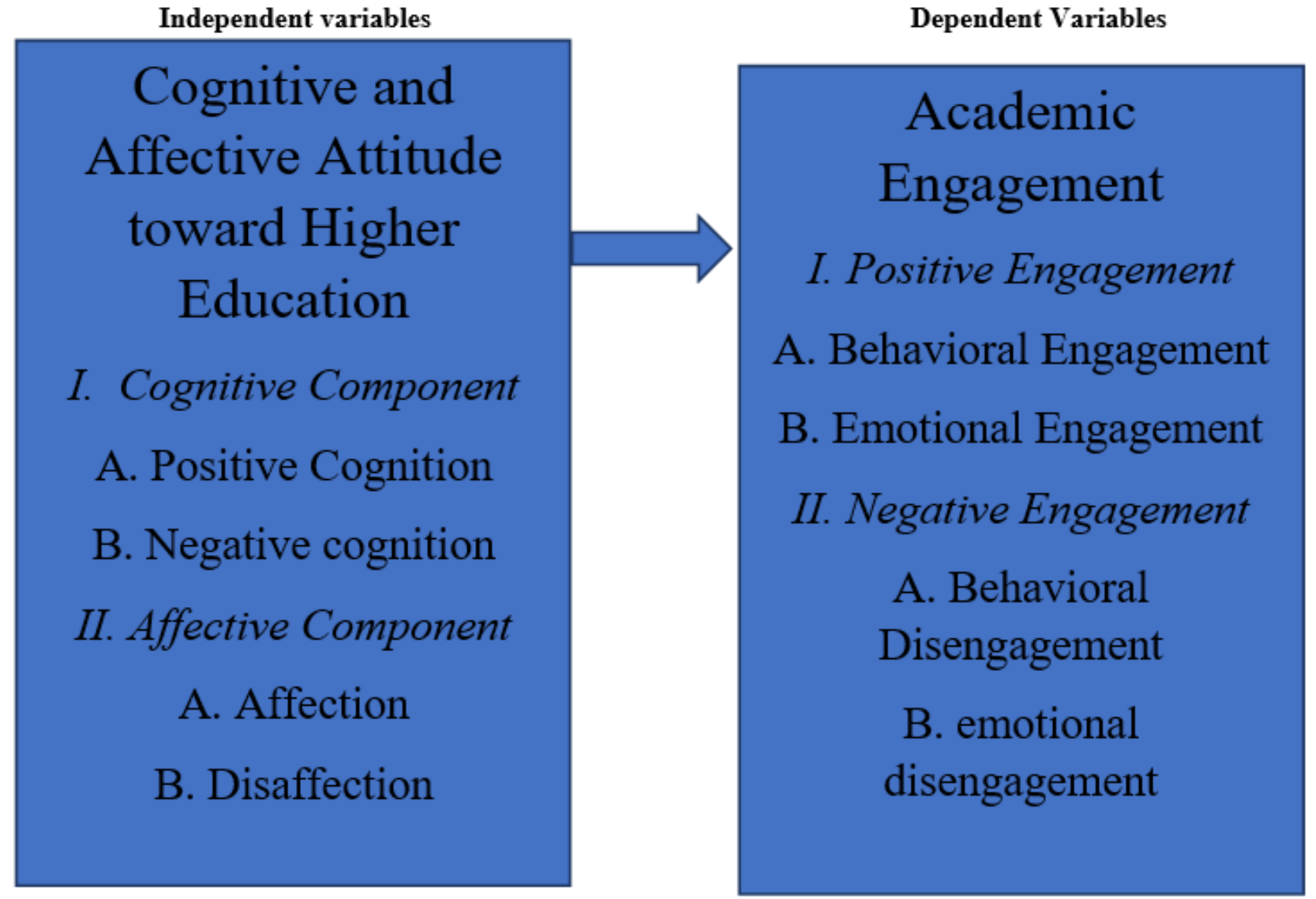

Fig.1: The conceptual framework reflects the independent and dependent variables which explains that attitude toward higher education affects academic engagement of students.

\section{Statement of the problems}

The study wants to determine the relationship between attitude of students toward higher education and their academic engagement, particularly to seek the answer for the following questions:

1. What is the cognitive attitude of students toward higher education in terms of

a. Positive cognition

b. Negative cognition

2. What is the affective attitude of students toward higher education in terms:

a. Affection (Positive)

b. Disaffection (Negative)

3. What is the academic engagement of students in terms of

a. Behavioral engagement

b. Emotional engagement

4. What is academic disengagement of students in terms of behavioral and emotional disengagement?
5. Is there a relationship between cognitive and affective attitude toward higher education and academic engagement of students?

\section{Assumptions}

The study assumes that students' attitude toward higher education affects their academic engagement and it can be measured. The study also assumes that the questionnaires are valid and the answers of students are objective.

\section{Hypothesis}

Ajzen (1985, 1987), Ajzen \& Madden, (1986) have argued that attitudes affect the human behavior and base on this theory, the current study argues that students' attitude toward higher education affects their academic engagement.

\section{Scope and delimitation of the study}

The study limited itself to measure the students' attitude toward higher education of and academic engagement of Divine Word Colleges' students in Ilocos Region. It limits itself to measure the cognitive and affective attitude and academic engagement. 


\section{METHODOLOGY}

The study was carried out through appropriate research methodology such as research design, data gathering instruments, population, locale of the study, data gathering procedures and statistical treatment of data.

\section{Research Design}

Since the study is a quantitative research and therefore it used descriptive correlational research designand aided by inquiry to determine the level of attitudes of students toward higher education and their academic engagement. The nature of descriptive research is to describe what is found in the data collected through questionnaires and statistical treatment. It is also used to describe profiles, frequency distribution, describe characteristics of people, situation, phenomena or relationship variables. In short, it describes "what is" about the data (Ariola, 2006, cited by Abun, 2019).

In line with the current study, descriptive correlational method was deployed. The study determines the level of attitude toward higher education and its correlation with the academic engagement. This was to determine what the dominant attitude of students toward higher education were and what particular attitudes affects the academic engagement of students.

\section{Locale of the Study}

The locale of the study was Divine Word Colleges in Ilocos Region which is composed of Divine Word College of Vigan and Divine Word College of Laoag. Divine Word College of Vigan belonged to the Province of Ilocos Sur and located within the heritage city of Vigan. Divine Word College of Laoag however, is located in Laoag City, Ilocos Norte. Divine Word Colleges in Region I are Statistical Range

4.21-5.00

$3.41-4.20$

$2.61-3.40$

$1.81-2.60$

$1.00-1.80$

\section{Descriptive Interpretation} Strongly agree

Agree Important

Somewhat agree

Disagree

Strongly disagree

Not Important

\section{FINDINGS}

The findings of the study are presented according to the statement of the problems of the study. The study was to determine the relationship between the attitude of students toward higher education and their academic engagement. It was specifically to answer the following questions: run by the Congregation of the Divine Word Missionaries or known as Society of the Divine Word or in Latin, Societas Verbi Divini (SVD).

\section{Population}

The population of the study was composed of all second year College Students of Divine Word Colleges in Ilocos region. Since the total numbers of students are limited, and therefore total enumeration is the sampling design of the study.

\section{Data Gathering instruments}

The study utilized validated questionnaires. The questionnaires were adapted from Public Attitude on Higher Education of Immerwahr (2003) and Motivational Perspective on Engagement and Disaffection questionnaires of Skinner, et.al (2009)

\section{Data Gathering Procedures}

In the process of data gathering, the researcher sent letters to the President of the Colleges, requesting them to allow the researcher to flow his questionnaires in the college. The researcher personally met the Presidents and students and requested them to answer the questionnaires.

The retrieval of questionnaires was arranged between the President's representative and the researcher with the help of employees and faculty of the college.

\section{Statistical Treatment of Data}

In consistent with the study as descriptive research, therefore descriptive statistics was used. The weighted mean is used to determine the level of attitude toward higher education and academic engagementand the Pearson $r$ was used to measure the correlation of attitudes toward higher education and academic engagement.

The following ranges of values with their descriptive interpretation will be used:
Somewhat Important

Not Very Important
1. What is the cognitive attitude of students toward higher education in terms of

a. Positive cognition

b. Negative cognition 
Table 1. Student's Attitude toward Higher Education as to Cognitive Component

\begin{tabular}{|c|c|c|c|}
\hline \multicolumn{2}{|c|}{ Cognitive Component } & Mean & DR \\
\hline \multicolumn{4}{|c|}{ a. Positive Component } \\
\hline 1 & Higher education is useful for my future employment. & 4.30 & A \\
\hline 2 & Higher education is necessary for improving quality of life & 4.19 & A \\
\hline 3 & Higher education is indispensable in updating my knowledge and skills & 4.02 & A \\
\hline 4 & Higher education should be for all & 4.24 & A \\
\hline 5 & Higher education is the only way to get a better job. & 3.86 & A \\
\hline \multirow[t]{2}{*}{6} & Higher education is necessary for a person to be successful in today's work world & 3.89 & A \\
\hline & Composite Mean & 4.08 & $\mathrm{~A}$ \\
\hline \multicolumn{4}{|c|}{ b. Negative Component } \\
\hline 1 & Higher education is not important & 2.09 & $\mathrm{D}$ \\
\hline 2 & There are many ways to succeed without college education. & 2.61 & SWA \\
\hline 3 & $\begin{array}{l}\text { Higher education is irrelevant because people can get a job after Senior High } \\
\text { School. }\end{array}$ & 2.61 & SWA \\
\hline 4 & Higher education is not the only way to make our life better. & 2.81 & SWA \\
\hline \multirow[t]{2}{*}{5} & Higher education is not necessary & 2.53 & $\mathrm{D}$ \\
\hline & Composite Mean & 2.53 & $\mathrm{D}$ \\
\hline
\end{tabular}

Legend

4.21-5.00

$3.41-4.20$

$2.61-3.40$

$1.81-2.60$

$1.00-1.80$

As it is indicated in the composite mean, it shows that as a whole, students' attitude toward higher education, in terms of its positive component, is 4.08 which is interpreted as agree or students consider higher education as important. This overall composite mean is supported by its single mean. Taking it singly, the students agree that higher education is useful for employment (4.30), for the improvement of the quality of life (4.19), for updating knowledge and skills (4.02), to get a better job (3.86), to be successful in today's work world (3.89) and they agree that higher education should be for all (4.28).

In terms of its negative component, as shown in its composite mean, it reveals that as a whole, students' attitude toward
Very Important

Important

Somewhat Important

Not Important

Not Very Important

higher education in terms of its negative component, is 2.53 which is translated as "disagree".It is lower that its positive component. Taking it singly, students did not totally agree or agree but disagree that higher education is not important (2.09), and higher education is not necessary (2.53) but they somewhat agree that there are many ways to succeed without college education (2.61), higher education is irrelevant because people can get a job after Senior High School (2.61) and not the only way to make life better (2.81).

2. What is the affective attitude of students toward higher education in terms of:

a. Affection (Positive)

b. Disaffection (Negative) 
Table 2. Student's Attitude toward Higher Education as to Affective Component

\begin{tabular}{|c|c|c|c|}
\hline \multirow{2}{*}{\multicolumn{4}{|c|}{ Affective Component }} \\
\hline & & & \\
\hline 1 & Higher education is interesting. & 4.11 & A \\
\hline 2 & Higher education is enjoyable. & 4.09 & A \\
\hline 3 & Higher education excites me. & 3.80 & A \\
\hline 4 & Higher education makes me great. & 3.90 & A \\
\hline \multicolumn{2}{|c|}{ Composite Mean } & 3.98 & $\mathbf{A}$ \\
\hline \multicolumn{4}{|c|}{ Disaffection } \\
\hline 1 & Higher education makes me nervous. & 2.94 & SWA \\
\hline 2 & Just thinking of higher education is stressful. & 3.00 & SWA \\
\hline 3 & Thinking of higher education makes me upset & 2.71 & SWA \\
\hline 4 & Higher education is not exciting because so many things to do. & 2.63 & SWA \\
\hline 5 & Higher education worries me. & 2.80 & SWA \\
\hline 6 & Higher education worries my parent. & 2.80 & SWA \\
\hline \multicolumn{2}{|c|}{ Composite Mean } & 2.81 & SWA \\
\hline
\end{tabular}

\section{Legend}

4.21-5.00

$3.41-4.20$

$2.61-3.40$

$1.81-2.60$

$1.00-1.80$

\section{Strongly agree}

Agree

Somewhat agree

Disagree

Strongly disagree
As reflected on table and on its composite mean, it reveals that as a whole, students' attitude toward higher education in terms of their affection is 3.98 which is interpreted as "agree" or "important". Taking it singly, the data shows that students agree that higher education is interesting (4.11), enjoyable (4.09), exciting (3.80), and making them great (3.90).

However, though the students agree in terms of their affection toward higher education, but in terms of its disaffection, as a whole, it appears that attitude of students toward higher education is 2.81 which mean that students do not totally agree or agree but "somewhat agree. Students somewhat agree that higher education makes them nervous (2.94), stressful (3.00), upset (2.71), worried (2.80), and worries their parent (2.80) and it does not excite them because there are many things to do (2.63).

\section{What is the academic engagement of students in terms of a. Behavioral engagement \\ b. Emotional engagement}

Table 3. Students' Academic Engagement as to Behavioral and Emotional Engagement

\begin{tabular}{|l|l|l|l|}
\hline \multicolumn{2}{|l|}{ Positive Engagement } & Mean & DR. \\
\hline a. Behavioral Engagement & 4.06 & A \\
\hline 1 & I try hard to do well in the school & 4.03 & A \\
\hline 2 & In class, I work hard as I can & 3.84 & A \\
\hline 3 & When I am in class, I participate in class discussion & 4.00 & A \\
\hline 4 & I pay attention in class & 3.96 & A \\
\hline 5 & When I am in class, I listen carefully & $\mathbf{3 . 9 8}$ & A \\
\hline Composite Mean & & \\
\hline b. Emotional Engagement & 3.74 & A \\
\hline 1 & When I am in class, I feel good & & \\
\hline
\end{tabular}




\begin{tabular}{|l|l|l|l|}
2 & When we work on something in class, I feel interested. & 3.71 & $\mathrm{~A}$ \\
\hline 3 & Class is fun & 3.81 & $\mathrm{~A}$ \\
\hline 4 & I enjoy learning new things in class & 3.92 & $\mathrm{~A}$ \\
\hline 5 & When we work on something in class, I get involved. & 3.69 & $\mathrm{~A}$ \\
\hline Composite Mean & $\mathbf{3 . 7 7}$ & $\mathrm{A}$ \\
\hline
\end{tabular}

\section{Legend}

4.21-5.00

Strongly agree

$3.41-4.20$

Agree

$2.61-3.40$

Somewhat agree

$1.81-2.60$

Disagree

$1.00-1.80$

Strongly disagree

Based on its composite mean, as a whole, it shows that students' academic engagement particularly behavioral engagement is 3.98 which can be understood as "agree". Even when taking them singly, it reveals that students agree that they try hard to do best in the school (4.06), work hard as they can (4.03), participate in class discussion (4.00), and listen carefully (3.96).

As it is in their behavioural engagement, as a whole, it also shows that students' academic engagement in terms of emotional engagement is 3.77 which is interpreted as "agree". Though they did not totally agree but agree that when they are in class, they feel good (3.74), interested (3.71), enjoying learning new things (3.92), get involved (3.69) and class is fun (3.81).

4. What is academic disengagement of students in terms of behavioral and emotional disengagement?

Table 4. Student's Academic Disengagement as to Behavioral and Emotional Disengagement.

\begin{tabular}{|c|c|c|c|}
\hline \multicolumn{2}{|c|}{ Negative Engagement } & Mean & DR. \\
\hline \multicolumn{4}{|c|}{ a. Behavioral Disengagement } \\
\hline 1 & When I am in class, I just act like I am working. & 3.21 & SWA \\
\hline 2 & I don't try very hard at school. & 2.91 & SWA \\
\hline 3 & In class, I do just enough to get by. & 3.08 & SWA \\
\hline 4 & When I am in class, I think about other things. & 3.06 & SWA \\
\hline 5 & When I am in class, my mind wanders. & 3.11 & SWA \\
\hline \multicolumn{2}{|c|}{ Composite Mean } & 3.07 & SWA \\
\hline \multicolumn{4}{|c|}{ b. Emotional Disengagement } \\
\hline 1 & When we work on something in class, I feel bored. & 2.60 & $\mathrm{D}$ \\
\hline 2 & When my teacher explains new materials, I feel bored. & 2.55 & $\mathrm{D}$ \\
\hline 3 & When we start something new in class, I feel nervous. & 2.87 & SWA \\
\hline 4 & When we work on something in class, I feel discouraged. & 2.47 & $\mathrm{D}$ \\
\hline 5 & When I am working on my classwork, I feel mad. & 2.52 & $\mathrm{D}$ \\
\hline \multicolumn{2}{|c|}{ Composite Mean } & 2.60 & D \\
\hline
\end{tabular}

Legend

4.21-5.00

$3.41-4.20$

2.61-3.40
Strongly agree

Agree

Somewhat agree 
$1.81-2.60$

$1.00-1.80$
Disagree

Strongly disagree
Looking into students' academic disengagement, as indicated by its composite mean, as a whole, it appears that students' academic disengagement in terms of behavioral disengagement is 3.07 which is understood as "somewhat agree". It means that they somewhat agree that when they are in class, they just act as if they were working (3.21), they do just enough to get by (3.08), when they are in class, they think about other things (3.06), and their mind wanders (3.11) and thus they agree that they do not try very hard in the school ( 2.91).

It is different when it comes to their emotional disengagement. As it is indicated in its composite mean, it reveals that as a whole, students' academic disengagement in terms of its emotional disengagement is 2.60 which mean "disagree". It means that students disagree that when they work on something in class, they feel bored (2.60), when their teachers explain new materials, they feel bored (2.55), when they work on something, they feel discouraged (2.47), when they are working on their classwork, they feel mad (2.52) but they somewhat agree that they start something new in

class (2.87).

5. Is there a relationship between cognitive and affective attitude toward higher education and academic engagement of students?

Table 5: The Relationship between cognitive and affective attitude and academic engagement.

\begin{tabular}{|c|c|c|c|c|c|}
\hline & & $\begin{array}{c}\text { Positive } \\
\text { Engagement } \\
\text {-Behavioral }\end{array}$ & $\begin{array}{c}\text { Positive } \\
\text { Engagement } \\
\text { - Emotional }\end{array}$ & $\begin{array}{c}\text { Negative } \\
\text { Engagement- } \\
\text { Behavioral }\end{array}$ & $\begin{array}{c}\text { Negative } \\
\text { Engagement- } \\
\text { Emotional }\end{array}$ \\
\hline \multirow{3}{*}{ Cognitive-Positive } & Pearson Correlation & $.364^{* *}$ & $.234^{* *}$ & .034 & -.092 \\
\hline & Sig. (2-tailed) & .000 & .001 & .634 & .195 \\
\hline & $\mathrm{N}$ & 201 & 201 & 201 & 201 \\
\hline \multirow{3}{*}{ Cognitive-Negative } & Pearson Correlation & -.123 & -.095 & .072 & $.202^{* *}$ \\
\hline & Sig. (2-tailed) & .083 & .179 & .307 & .004 \\
\hline & $\mathrm{N}$ & 201 & 201 & 201 & 201 \\
\hline \multirow{3}{*}{ Affection } & Pearson Correlation & $.295^{* *}$ & $.271^{* *}$ & .036 & -.095 \\
\hline & Sig. (2-tailed) & .000 & .000 & .610 & .179 \\
\hline & $\mathrm{N}$ & 201 & 201 & 201 & 201 \\
\hline \multirow{3}{*}{ Disaffection } & Pearson Correlation & -.054 & -.107 & $.146^{*}$ & $.312^{* *}$ \\
\hline & Sig. (2-tailed) & .448 & .131 & .039 & .000 \\
\hline & $\mathrm{N}$ & 201 & 201 & 201 & 201 \\
\hline
\end{tabular}

**. Correlation is significant at the 0.01 level (2-tailed).

*. Correlation is significant at the 0.05 level (2-tailed).

As it is indicated in the Pearson $r$ correlation, it reveals that there is a significant correlation between positive cognition toward higher education and behavioral and emotional academic engagement of students at 0.1 level (2-tailed). While negative cognition correlates to emotional disengagement.

In terms of affective attitude toward higher education, the Pearson $r$ correlation indicates that students' affection toward higher education correlates significantly at 0.01 level (2-tailed) to the behavioral and emotional academic engagement of students. While its disaffection toward higher education correlates significantly at 0.05 level (2tailed) to behavioral disengagement and at 0.01 level (2tailed) to emotional disengagement.

\section{CONCLUSION}

Based on the finding, the study concludes that students' cognitive attitude toward higher education in terms of its positive attitude is 4.08 which means "agree" and their 
cognitive attitude in terms of negative attitude toward higher education is 2.53 which means disagree. While affective attitude in terms of affection (positive component) is 3.98 which means agree. However, in terms of its disaffection or negative component is 2.81 which means somewhat agree.

In terms of academic engagement., students have 3.98 for behavioral engagement and 3.77 for emotional engagement in which they all agree that they are behaviorally and emotionally engaged in their academic activities.However, in terms of its academic disengagement, students somewhat agree they are behaviorally disengaged and therefore they disagree that they are emotionally disengaged in their academic activities.

Finally, there is a significant correlation between cognitive and affective attitude toward higher education and academic engagement of students. Therefore, hypothesis of the study, that the attitude of students toward higher education affects their academic engagement is accepted.

\section{REFERENCES}

[1] Abun, D., \& P.Racoma, A.P. (2017). Environmental Attitude and Environmental Behavior of Catholic Colleges' Employees in Ilocos Sur, Philippines. Texila International Journal of Academic Research, Volume 4, Issue 1, June 2017.

[2] Abun,D., Foronda, S.L.G., Agoot, F., Belandres, M.L.V., \& Magallanez, Th. (2018).

[3] Measuring entrepreneurial attitude and entrepreneurial intention of ABM grade XII, Senior High School Students of Divine Word Colleges in Region I, Philippine. International Journal of Applied Research, Vol. 4, Issue, 4, 2018.

[4] Ajzen, I. (1993). New Directions in Attitude Measurement. New York: Walter de Gruyter.

[5] Ajzen, I., \& Fishbein, M. (1977). Attitude - Behavior Relations: A Theoretical Analysis and review of Empirical Research. Psychological Bulletin, 84, 888-918.

[6] Ajzen, I., \& Fishbein, M. (2000). Attitudes and the AttitudeBehavior relation: Reasoned and Automatic Processes. In W. Stroebe \& M.Hewstone (Eds.). European Review of Social Psychology, Vol. 11, pp. 1-33. Chichester, UK: Wiley.

[7] Allen, H. (2007). Why is Higher Education Important? Retrieved from http://www.crosswalk.com/family/homeschool/

[8] Allport, G.W. (1954). The Historical Background of Modern Social Psychology. In Lindzay, G. (Ed.). Handbook of Social Psychology, Vol. 1, pp. 3-56. Cambridge, MA: AddisonWesley.

[9] Allport, Gordon. (1935). "Attitudes," in A Handbook of Social Psychology, ed. C. Murchison. Worcester, MA: Clark University Press, 789-844.
[10] Amstrong, W. R. (1996). The Relationship between Culture and Perception of Ethical Problems in International Marketing, Journal of Business Ethics, Volume: 15, Issue: 11, Pages: 1199-1208.

[11] Audas, R., \& Willms, J. D. (2002). Engagement and dropping out of school: A life-course perspective. Applied Research Branch, Human Resources Development Canada. Retrieved March 15, 2015 from http://sbisrvntweb.uqac.ca/archivage/15292281.pdf

[12] Banaji, M.R. \& Heiphetz, L. (2010). Attitudes. In S.T. Fiske, D.T. Gilbert \& G. Lindzey (Eds). Handbook of Social Psychology ( $5^{\text {th }}$ ed, Vol. 1, pp. 353-393. Hoboken, NJ: John Wiley \& Sons.

[13] Bem, D.J. (1970). Beliefs, Attitudes and Human Affairs. Belmont, CA: Brooks/Cole.

[14] Benjamin, T.B. Public Perception of Higher Education. Journal of Oxford Review of Education, Vol. 19, Issue I, pp. 47-63.

[15] Brown, A. (1995). Organizational Culture. London: Pitman Publishing.

[16] Cherry, K. (2019). Attitudes and Behaviors in Psychology. Very Well Mind. Retrieved from https://www.verywellmind.com/attitudes-how-they-formchange-shape-behavior-2795897

[17] Corey, S. M. (1937). Professed attitudes and actual behavior. Journal of Educational Psychology, 28(4), 271280.http://dx.doi.org/10.1037/h0056871

[18] Curran, J. M., \& Rosen, D. E. (2006). Student Attitudes Toward College Courses: An Examination of Influences and Intentions. Journal of Marketing Education, 28(2), 135148. https://doi.org/10.1177/0273475306288401.

[19] DeFleur, M.L. \& Westie, F.R. (1958). Verbal Attitude and Overt Acts: An Experiment on the Salience of Attitude. American Sociological Review 23(6):667.

[20] Donald, M. (2002). A Mind So Rare: The Evolution of Human Consciousness. New York: W.W. Norton \& Company, Inc.

[21] Eagly, Alice H., and Shelly Chaiken. 1998. "Attitude, Structure and Function." In Handbook of Social Psychology, ed. D.T. Gilbert, Susan T. Fisk, and G. Lindsey, 269-322. New York: McGowan-Hill.

[22] Edwards, A.L. (1957). Technique of Attitude Scale Construction. New York: Appleton-Century- Crofts.

[23] Finn, J. D., Pannozzo, G. M., \& Voelkl, K. E. (1995). Disruptive and inattentive-withdrawn behavior and achievement among fourth graders. The Elementary School Journal, 95, 421-454.

[24] Fishbein, M., \& Ajzen, I. (1975). Beliefs, Attitude, Intention and behavior: An Introduction to theory and research. Reading, MA: Addison-Wesley.

[25] Fitzsimmons, J.R., Douglas, E.J. (2005). "Entrepreneurial Attitudes and Entrepreneurial 
[26] Intentions: A Cross-Cultural Study of Potential Entrepreneurs in India, China, Thailand And

[27] Australia", Babson-Kauffman Entrepreneurial Research Conference, Wellesley, MA. June 2005.

[28] Fredricks, J. A., Blumenfeld, P. C., \& Paris, A. H. (2004). School engagement: Potential of the concept, state of the evidence. Review of Educational Research, 74, 59-109.

[29] Hilgard, E.R. (1980). The trilogy of Mind: Cognition, affection, and conation. Journal of the History of the Behavioral Sciences, 16, pp. 107-117.

[30] Meyer, D. K., \& Turner, J. C. (2002). Discovering emotion in classroom research. Educational Psychologist, 37, 107114.

[31] Hidi, S., Renninger, K. A., \& Krapp, A. (2004). Interest, a motivational variable that combines affective and cognitive functioning. In D. Dai \& R. Sternberg (Eds.), Motivation, emotion, and cognition: Perspectives on intellectual development and functioning (pp. 89-115). Mahwah, NJ: Lawrence Erlbaum.

[32] ICEF Monitor (2013). Philippines Creates Opportunities in Overhaul of K-12 Education System. Retrieved from http://monitor.icef.com/2013/08/philippines-createsopportunities-in-overhaul-of-k-12-education-system/

[33] Imerwahr, J. (2004). Public Attitude on Higher Education: A Trend Analysis, 1993-2003. The National Center for Public Policy and Higher Education. Retrieved from https://www.publicagenda.org/files/public_attitudes_on_hig her_education.pdf

[34] Lawler, M.S. (2006). William James' Psychological Pragmatism: Habit, Belief and Purposive Human Behavior. Cambridge Journal of Economics, Vol. 30, Issue 3, pp. 321345.

[35] Malmström, M., \& Öqvist, A. (2018). Students' attitudes and intentions toward higher education as determinants for grade performance. International Journal of School \& Educational Psychology, Volume 6, 2018 - Issue 1.

[36] Maheswari, V., \&Haridas, R., (2013). A Study on Determinants of Student's Attitude Towards Higher Education. IOSR Journal of Business and Management (IOSR-JBM), Volume 13, Issue 4 (Sep. - Oct. 2013), PP 6062.

[37] Main, R. (2004). The rupture of time: Synchronicity and Jung's critique of modern western culture. Routledge.

[38] Mandal, S., Banik, S., Das, A., \& Trivedi, S.K. (2018). Attitudes of Graduate Students toward Higher Studies. Journal of Emerging Technologies and Innovative Research (JETIR), Vol. 5, Issue 1.

[39] Mawi, Ch.L., \& Maisnam, P. (2014). Attitude and Perception of the Students towards Higher Secondary Education in Churachandpur District of Manipur. International Journal of Interdisciplinary and Multidisciplinary Studies (IJIMS), 2014, Vol 2, No.1, 97104.
[40] Muhammad Afzal* and Muhammad Rashid**(2018). Higher Education in Asian Context: A Study of Students' Attitude towards Higher Education in Pakistani Universities. Bulletin of Education and Research August 2018, Vol. 40, No. 2 pp. 137-145.

[41] Newmann, F. M., Wehlage, G. G., \& Lamborn, S. D. (1992). The significance and sources of student engagement. In F. M. Newmann (Ed.), Student engagement and achievement in American secondary schools (pp.11-39). New York: Teachers College Press.

[42] Pearson, R., O'Neal, E., Laura Hersh Salganik, L.S. \& McMillen, M. (1997). Public Attitudes Toward Secondary Education: The United States in an International Context. National Center for Educational Statistics. Retrieved from https://nces.ed.gov/pubsearch/pubsinfo.asp?pubid=97595.

[43] Pekrun, R., Goetz, T., Titz, W., \& Perry, R. P. (2002). Academic emotions in students' self-regulated learning and achievement: A program of qualitative and quantitative research. Educational Psychologist, 37, 91-105.

[44] Pillai, S. \& Joseph, S. (n.d). Students' Attitude toward Higher Education. Retrieved from https://www.academia.edu/35051113/Students_Attitude_To wards_Higher_Education.

[45] Ridley, M. (2003). A Review of Nature via Nurture: Genes, Experience, and What Makes Us Human. New York: HarperCollins.

[46] Rosenberg, M.J. \& Hovland, C.I. (1960). Cognitive, Affective and Behavioral Components of Attitudes. In Hovland, C.I. \& Rosenberg, M.J. (Eds). Attitude Organization and Change, pp. 1-14. New haven, CT: Yale University Press.

[47] Roy, A., \& Kareem, J. (2016). Attitude of Public towards Higher Education: Conceptual Analysis. Scholedge International Journal of Multidisciplinary \& Allied Studies, Vol. Vol.02, Issue 12 (2015) pp19-28.DOI: 10.19085/journal. sijmas021202.

[48] Schiefele, U. (2001). The role of interest in motivation and learning. In J. M. Collis \& S. Messick (Eds.), Intelligence and personality: Bridging the gap in theory and measurement (pp. 163-194). Mahwah, NJ: Lawrence Erlbaum.

[49] Schutz, P. A., \& DeCuir, J. T. (2002). Inquiry on emotions in education. Educational Psychologist, 37, 125-134.

[50] Skinner, E. A., Kindermann, T. A., \& Furrer, C. J. (2009). A Motivational Perspective on Engagement and ies.ccsenet.org International Education Studies Vol. 9, No. 12; 2016.

[51] Thomas, W.I., \& Znaniecki, F. (1918). The Polish Peasant in Europe and America (vol. 1). Boston: Bedger.

[52] Uyquiengco, M. (n.d). Benefits of the K-to-12 Curriculum for Filipino Students. Retrieved from https://ph.theasianparent.com/advantages-new-k-12curriculum.

[53] Watson, J.B. (1925). Behaviorism. New York: Norton. 
[54] Wehlage, G., Rutter, R., Smith, G., Lesko, N., \& Fernandez, R. (1989). Reducing the Risk: School as communities of support. Philadelphia: The Falmer Press.

[55] Weiner, B. (1985). An attributional theory of achievement motivation and emotion. Psychological Review, 92, 548573.

[56] Weiner, B. (1985). An attributional theory of achievement motivation and emotion. Psychological Review, 92, 548573.

[57] Wicker, A. W., \& Pomazal, R. J. (1971). The relationship between attitudes and behavior as a function of specificity of attitude object and presence of a significant person during assessment conditions. Representative Research in Social Psychology, 2(2), 26-31.

[58] Wood, W. (2000). "Attitude Change: Persuasion and Social Influence". Annual Review of Psychology. 51: 539570. doi:10.1146/annurev.psych.51.1.539.

[59] Zajonc, R. B. (1968). "Attitudinal effects of mere exposure". Journal of Personality and Social Psychology. Vol. 9, issue 2. 